\title{
Effect of diets varying in the type of dietary fibre and its combination with polyphenols on gut function, microbial activity and antioxidant status in rats
}

\author{
E. Żary-Sikorska ${ }^{1,5}$, J. Juśkiewicz², A. Jundziłł ${ }^{3}$ and J. Rybka ${ }^{4}$ \\ ${ }^{1}$ University of Science and Technology, Department of Microbiology and Food Technology, \\ Faculty of Agriculture and Biotechnology, Kordeckiego 20A, 85-225 Bydgoszcz, Poland \\ ${ }^{2}$ Institute of Animal Reproduction and Food Research, Polish Academy of Sciences, Tuwima 10, 10-748 Olsztyn Poland \\ ${ }^{3}$ Nicolaus Copernicus University, Collegium Medicum, Department of Regenerative Medicine \\ Karłowicza 24, 85-092 Bydgoszcz, Poland \\ ${ }^{4}$ Nicolaus Copernicus University, Collegium Medicum, Department and Clinic of Geriatrics \\ M. Curie Skłodowskiej 9, 85-094 Bydgoszcz, Poland
}

KEY WORDS: apple pomace, chicory, dietary fibre, polyphenols, fermentation, rats

Received: 22 December 2015

Revised: $\quad 19$ May 2016

Accepted: 26 August 2016
${ }^{5}$ Corresponding author:

e-mail: ezary@utp.edu.pl
ABSTRACT. The aim of the study was to assess the effects of dietary supplementation with chicory root meal (CHIC) or apple pomace (POM), containing both dietary fibre and polyphenols, on selected physiological parameters in rats. Forty Wistar rats were divided into 5 groups of 8 animals each and fed control (C) diet with $10 \%$ of cellulose or diets containing CHIC, POM, oligofructose (OLIGOF) or pectin (PEC) for 28 days. The supplements were added to experimental groups in order to obtain the corresponding to the $\mathrm{C}$ group the non-digestible carbohydrates content. Indices of caecal fermentation, antioxidant status, lipid peroxidation and lipid profile of rats were assessed. Supplementing POM and $\mathrm{CHIC}$ to rat diets decreased $(P \leq 0.05)$ the caecal $\mathrm{pH}$ and ammonia concentration, bacterial $\beta$-glucuronidase activity and increased the short-chain fatty acid concentration and pool size in comparison to the $C$ group. In POM group the triacylglycerol (TAG) and thiobarbituric acid-reactive substances concentration was lower in comparison to $C$ and to OLIGOF and $\mathrm{C}$ groups, respectively. The examined preparations significantly $(P \leq 0.05)$ decreased TAG and total cholesterol levels in blood, but had no influence on liver functioning parameters and antioxidant biomarkers such as sodium dismutase and glutathione peroxidase activity or antioxidant capacity of water- and lipidsoluble serum fractions. So, supplementing rats with POM and CHIC beneficially modulated microbial activity in the caecum and blood lipid profile.

\section{Introduction}

The physiological effect of concomitant availability of polyphenols and fibre in a diet is not well recognized. However, synergetic effect of dietary fibre and polyphenols was reported by Aprikian et al. (2003) who observed that pectins and polyphenols, when administered together to rats, exert stronger positive impact on caecal fermentation and blood lipid profile than each fraction individually. Free or simple polyphenol conjugates of small molecular weight are absorbed in the 
upper gastrointestinal tract. However, as dietary polyphenols are present in the form of esters, polymers or glycosylated particles must be hydrolysed by the intestinal enzymes or the colonic microflora prior to absorption. Polyphenols deglycosylation, dehydroxylation and demethylation may be conducted by bacterial enzymes (Olthof et al., 2001). On the other hand, non-digestible carbohydrates, e.g., pectins and fructooligosaccharides (FOS), are not hydrolysed by pancreatic enzymes in the upper part of the gut but they are transported in whole to the large intestine where they may increase susceptibility of phenolic compounds to microbial metabolism (Juśkiewicz et al., 2011).

Apples and chicory contain specific fibre types and polyphenols. Apples contain $2-3 \%$ of fibre, $50 \%$ from this in soluble form (pectins), which is more readily fermented than its cereal counterpart. Also, apples contain approximately $2 \mathrm{~g}$ of polyphenols per $\mathrm{kg}$ of fresh mass. Importantly, the phenolic compounds concentration (flavonoids and phenolic acids) in the whole apple is higher in a peel than in a pulp (Wolfe and Liu, 2003). Chicory fibre consists of inulin-type fructans with different degrees of polymerization (DP): oligofructose 3-10 DP and inulin ->10 DP (Milala et al., 2009). FOS and inulin can increase acidification of digesta, growth of health-promoting bacteria (Bifidobacterium) and short chain fatty acids (SCFA) production in the large intestine. They also protect polyphenols against degradation in the digestive tract and increase their absorption, leading to an improvement in the body antioxidant defence system (Juśkiewicz et al., 2011). Main active phenolic compounds present in chicory leaves and roots are mono- and dicaffeoylquinic acids (MonoCQA and DiCQA, respectively) and chicoric acid (Olthof et al., 2001).

It was hypothesized that the presence of polyphenolic fraction in dietary fibre preparations may exert physiological effects on the organism, both locally in the intestinal tract and systemically. Therefore, the aim of the study was to determine the effects of two unprocessed preparations, i.e. apple pomace (POM) and chicory root meal (CHIC), on the gut function, caecal fermentation and antioxidant status in rats, and to compare them with the influence of pectin and oligofructose.

\section{Material and methods}

\section{Plant material}

Dietary supplements were: apple pectin (PectinE 440(i); Fruit and Vegetable Processing Plant
'Pektowin' Sp. z o.o.; Jasło, Poland) with galacturonic acid content $>74 \%$ of dry matter, oligofructose (Raftilose1P95, ORAFTI; Belgium), unprocessed POM and unprocessed CHIC.

POM was obtained from the manufacturer of clarified juices (ALPEX; Łęczeszyce, Poland). Fresh pomace, obtained from a dessert apple cultivar using enzyme-assisted pressing and the Bücher type press, was dried in a convection oven at $\leq 70{ }^{\circ} \mathrm{C}$ until the moisture content was lower than $5 \%$. Then it was sieved through a $3 \mathrm{~mm} / 5 \mathrm{~mm}$ mesh screen to remove seeds. The received fractions were ground in a disc mill to particles of $<0.6 \mathrm{~mm}$ in size.

CHIC was obtained from chicory grits produced industrially (ZPC Cykoria S.A.; Wierzchosławice, Poland) by the use of a convective dryer at $\leq 70{ }^{\circ} \mathrm{C}$. The dried chicory material was disintegrated in a ball grinder and sieved through a $0.8 \mathrm{~mm}$ mesh screen.

\section{Animals and diets}

The 4-week experiment was conducted on 40 male 49-day-old Crl:WI(Han) Wistar rats of $205.6 \pm 12.9$ g body weight (BW), as approved by the Local Ethical Commission for Experiments with Animals in Olsztyn (Poland). Rats were randomly divided into 5 groups of 8 rats each and housed individually in plexiglass cages (Tecniplast Spa.; Buguggiate, Italy) under standard conditions: temperature $21-22{ }^{\circ} \mathrm{C}$, relative humidity $55 \pm 10 \%$, intensive room ventilation 15-20 times/h with a $12 \mathrm{~h}$ light/dark cycle. Food and tap water were freely available. The experimental diets were modified with addition of apple pectin (PEC), apple pomace preparation (POM), oligofructose (OLIGOF) and unprocessed chicory root meal (CHIC). CHIC and POM were added to the diets at different doses so that the non-digestible carbohydrates content remained similar and corresponded to $10 \%$ of cellulose added to the control (C) group (Table 1). The POM and CHIC diets contained 0.027 and $0.017 \%$ of polyphenolic fraction, respectively, while the $\mathrm{C}$, PEC and OLIGOF diets were polyphenols free. Rats BW was recorded at the beginning and the end of the study, and diet intake was monitored daily to calculate the BW gain and feed conversion ratio (FCR).

At the end of the experiment the rats were anaesthetized with sodium pentobarbitone. Blood samples were taken from the caudal vena cava. Then, the rats were sacrificed by anaesthetic overdose and death was confirmed by cervical dislocation. After laparotomy, selected organs (liver, heart, lungs and kidneys) as well as segments of the gastrointestinal tract (small intestine, caecum and colon with their 
Table 1. Composition of diets, $\%$

\begin{tabular}{|c|c|c|c|c|c|}
\hline \multirow{2}{*}{ Indices } & \multicolumn{5}{|l|}{ Diets $^{1}$} \\
\hline & $\mathrm{C}$ & PEC & POM & OLIGOF & $\mathrm{CHIC}$ \\
\hline \multicolumn{6}{|l|}{ Ingredients } \\
\hline solid ingredients ${ }^{2}$ & 90 & 82.5 & 85 & 89.4 & 86.5 \\
\hline cellulose & 10 & - & - & - & - \\
\hline pectin $^{3}$ & - & 17.5 & - & - & - \\
\hline $\begin{array}{l}\text { unprocessed apple } \\
\text { pomace }\end{array}$ & - & - & 15 & - & - \\
\hline oligofructose $e^{4}$ & - & - & - & 10.6 & - \\
\hline $\begin{array}{l}\text { unprocessed } \\
\text { chicory root meal }\end{array}$ & - & - & - & - & 13.5 \\
\hline \multicolumn{6}{|l|}{ Nutrient content } \\
\hline total protein & 15.50 & 15.50 & 15.50 & 15.50 & 15.50 \\
\hline dietary fibre & 10.00 & 10.15 & 10.17 & 10.07 & 10.12 \\
\hline polyphenols & - & - & 0.027 & - & 0.017 \\
\hline \multicolumn{6}{|c|}{$\begin{array}{l}{ }^{1} \mathrm{C} \text { - control diet, PEC - diet with pectin, POM - diet with unprocessed } \\
\text { apple pomace, OLIGOF - diet with oligofructose, CHIC - diet with } \\
\text { unprocessed chicory meal; } 2 \% \text { : casein } 13.75 \text {, DL-methionine } 0.2 \text {, } \\
\text { soya protein isolate } 2.8-4 \text {, soyabean oil 8, cholesterol 0.5, vitamin mix } \\
\text { (AIN-93G-VM) 1, mineral mix (AIN-93G-MX) 3.5, maize starch up to 100, } \\
{ }^{3} \text { PectinE } 440 \text { (i) (Brouwland, Beverlo, Belgium), }{ }^{4} \text { oligofructose Rafti- } \\
\text { lose }{ }^{\circledR} \text { P95 (Beneo-Orafti, Oreye, Belgium) }\end{array}$} \\
\hline
\end{tabular}

contents) were removed and weighed. The small intestine, caecal and colon $\mathrm{pH}$ was measured using a microelectrode and $\mathrm{pH} / \mathrm{ION}$ meter (model 301; Hanna Instruments; Vila do Conde, Portugal). Samples of fresh digesta were weighed and used immediately for analysis of dry matter (dried at $105^{\circ} \mathrm{C}$ ) and ammonia concentration, while the determinations of microbial glycolytic activity as well as the concentration of SCFA were performed in samples stored at $-70^{\circ} \mathrm{C}$. The small intestine, caecum and colon's walls were flushed clean with ice-cold saline, blotted on filter paper and weighed as tissue mass. The mucosal samples of small intestine were collected by scraping with glass slides onto an ice-cooled glass plate, weighed and subsequently stored at $-70{ }^{\circ} \mathrm{C}$.

\section{Chemical analyses of plant material and experimental diets}

POM, CHIC and experimental diets were analysed in duplicate for dry matter, crude protein, fat, ash, total dietary fibre and insoluble dietary fibre using the AOAC International (2005) methods 934.01, 920.152, $930.09,940.26,985.29$ and 993.19 , respectively.

Phenolic determinations in CHIC were performed according to the procedure of Milala et al. (2009), using a Dionex HPLC system with a diode array detector (Germering, Germany) coupled with a $4 \mu \mathrm{m}$ Fusion-RP $80 \mathrm{~A}$ column $(150 \times 2.0 \mathrm{~mm}$; Phenomenex Synergi; Torrance, CA, USA). Extraction of polyphenolic compounds from POM was per- formed as follows: $0.5 \mathrm{~g}$ of each freeze-dried sample was mixed with $4 \mathrm{ml}$ of solvent ( $70 \%$ ethanol, $\mathrm{v} / \mathrm{v}$ ) and sonicated for $15 \mathrm{~min}$. After centrifugation at $4800 \mathrm{~g}$ for $5 \mathrm{~min}$, the supernatant was collected and the residue was re-extracted twice with $3 \mathrm{ml}$ of the same solvent to gain about $10 \mathrm{ml}$ pooled extracts. The ethanolic extracts, containing most of the soluble polyphenols, were analysed by a Dionex HPLC coupled with a Gemini 5-mm C18 110A column $(250 \times 4.6 \mathrm{~mm}$; Phenomenex Synergi; Torrance, CA; USA), as described previously by Juśkiewicz et al. (2012).

Carbohydrate determinations in CHIC were performed using a HPLC (Knauer Smartline with an RI K-2301 Knauer detector; Berlin, Germany), an Animex HPX 87C $(300 \times 7.8 \mathrm{~mm})$ column and water as a mobile phase (flow rate of $0.5 \mathrm{ml} \cdot \mathrm{min}^{-1}$ at $85^{\circ} \mathrm{C}$ ), as described previously by Juśkiewicz et al. (2011).

\section{Determination of disaccharidases activity}

Small intestinal disaccharidases activity (sucrase, maltase, lactase) was assayed by the Dahlqvist (1964) method with some modifications. The amount of the liberated glucose was measured spectrophotometrically in a mucosal homogenate supernatant. The enzyme activity was expressed as $\mu \mathrm{mol}$ of disaccharide hydrolysed per min per $g$ of protein. The protein content of the supernatant was estimated according to Lowry et al. (1951) method using bovine serum albumin as a standard.

\section{Measurements of microbial activity}

Ammonia from the fresh caecal digesta was extracted, trapped in a solution of boric acid in Conway's dishes and determined by direct titration with sulphuric acid. The activity of bacterial enzymes ( $\alpha$-and $\beta$-glucosidase, $\alpha$ - and $\beta$-galactosidase and $\beta$-glucuronidase) was measured by the rate of $p$ - or $o$-nitrophenol release from their nitrophenylglucosides according to the method described by Wronkowska et al. (2011). The amount of SCFA was measured using gas chromatography (Shimadzu GC-2010, Kyoto, Japan). Samples (0.2 g) were mixed with $0.2 \mathrm{ml}$ of formic acid, diluted with water and centrifuged at $7211 \mathrm{~g}$ for $10 \mathrm{~min}$. One $\mu 1$ of the supernatant was loaded onto a capillary column (SGE BP21, $30 \mathrm{~m} \times 0.53 \mathrm{~mm}$ ) using an on-column injector. The initial oven temperature of $85^{\circ} \mathrm{C}$ was raised to $180^{\circ} \mathrm{C}$ by $8^{\circ} \mathrm{C} \cdot \mathrm{min}^{-1}$, then maintained for $3 \mathrm{~min}$. The flame ionization detector and injection port temperatures were $180^{\circ} \mathrm{C}$ and $85^{\circ} \mathrm{C}$, respectively. 


\section{Analyses of biochemical blood indices and antioxidant status}

Activities of superoxide dismutase (SOD) in the erythrocyte lysate and glutathione peroxidase (GPx) in the heparinized blood were determined using reagents from Randox Laboratories Ltd. (Crumlin, Atrim, UK). Serum antioxidant capacities of watersoluble (ACW) and lipid-soluble (ACL) substances were determined by photochemiluminescence detection method using Photochem (Analytik Jena AG; Jena, Germany), as described previously by Juśkiewicz et al. (2011).

Serum from the remaining non-heparinized blood was obtained after solidification. Glucose, total cholesterol (TC), high-density lipoprotein (HDL) cholesterol content and triacylglycerol (TAG) concentrations as well as alanine aminotransferase (ALT) and aspartate aminotransferase (AST) serum activities were determined with commercial diagnostic kits (Alpha Diagnostics; Warsaw, Poland).

The extent of lipid peroxidation in kidneys, lungs, heart and liver was measured spectrophotometrically by quantifying thiobarbituric acidreactive substances (TBARS) content (Uchiyama and Mihara, 1978). TBARS content was calculated from a standard curve for malondialdehyde and expressed as $\mu \mathrm{mol} \cdot 100 \mathrm{~g}^{-1}$ tissue.

\section{Statistical analyses}

All data is presented as means with their pooled SEM. The results were assessed using one-way analysis of variance (ANOVA) and the Duncan's multiple range test. Differences at $P<0.05$ were considered significant. The calculations were made using the STATISTICA 12.0 ENG software package (StatSoft Inc., Tulsa, OK, USA).

\section{Results}

\section{Chemical composition of POM and CHIC}

POM contained, \%: dry matter (DM) 94.9, crude ash 1.4 , crude protein 7.1 , crude fat 2.5 , total dietary fibre 67.8 , soluble dietary fibre $8.8, \mathrm{~N}$-free extractives 16.1. Phenolic fraction of POM consisted of, $\mathrm{mg} 100 \mathrm{~g}^{-1}$ : chlorogenic acid 6.9, phlorizin 42 , flavanols 2.1, quercetin and its glycosides 66.1, total polyphenols 117.1. CHIC preparation contained, \%: DM 97.3, ash 3.8, protein 5.6, fat 1.7, glucose 2.7 , fructose 5.7 , sucrose 15.9 , fructans 60.1 including oligofructose 14.1, inulin 46 and phenolic fraction 0.5 (0.3 MonoCQA and 0.2 DiCQA).

\section{Body weight, feed intake and feed conversion ratio}

The lower body weight (BW) gain and higher feed conversion ratio (FCR) were demonstrated in rats fed PEC diet as compared to those fed C, POM and OLIGOF diets (Table 2). Similarly, daily feed intake was lower in rats fed PEC diet in comparison to other animals (except rats fed OLIGOF diet) (Table 2).

Table 2. Growth performance of rats

\begin{tabular}{lllllll}
\hline Indices & Diet $^{1}$ & & & & \\
\cline { 2 - 6 } & $\mathrm{C}$ & PEC & POM & \multicolumn{2}{l}{ OLIGOF CHIC } & SEM \\
\hline Initial BW, g & 206 & 205 & 206 & 206 & 205 & 1.61 \\
Final BW, g & $309^{\mathrm{a}}$ & $281^{\mathrm{b}}$ & $317^{\mathrm{a}}$ & $312^{\mathrm{a}}$ & $299^{\mathrm{ab}}$ & 3.35 \\
BW gain, g & $103^{\mathrm{a}}$ & $79.6^{\mathrm{b}}$ & $112^{\mathrm{a}}$ & $107^{\mathrm{a}}$ & $95.5^{\mathrm{ab}}$ & 2.96 \\
Daily feed intake, g & $557^{\mathrm{a}}$ & $505^{\mathrm{b}}$ & $561^{\mathrm{a}}$ & $529^{\mathrm{ab}}$ & $545^{\mathrm{a}}$ & 6.18 \\
FCR, $\cdot \mathrm{g}^{-1}$ & $5.50^{\mathrm{b}}$ & $6.41^{\mathrm{a}}$ & $5.11^{\mathrm{b}}$ & $5.06^{\mathrm{b}}$ & $5.79^{\mathrm{ab}}$ & 0.14 \\
\hline
\end{tabular}

${ }^{1}$ see Table 1; BW - body weight, FCR - feed conversion ratio; $\mathrm{ab}$ - means with different superscripts within a row are significantly different at $P \leq 0.05$

\section{Digestive tract parameters in rats fed experimental diets}

Feeding rats with POM and PEC diets increased the weight of small intestine with digesta when compared to $\mathrm{C}$ group. The small intestine weight observed in the PEC group was the highest among all groups (Table 3 ).

Neither supplementing rats with POM nor CHIC affected the mucosal sucrase and lactase activity, whereas maltase activity was increased in animals fed PEC diet in comparison to all remaining groups (Table 3).

The $\mathrm{pH}$ of small intestinal digesta substantially was lower in the OLIGOF group in comparison to other groups (Table 3).

Regarding the effect on the caecal and colonic parameters, the greatest mass of these both tissues was observed upon OLIGOF administration. The caecal mass was significantly higher in PEC group when compared to C, POM and CHIC groups. The mass of caecal digesta was greater in rats fed OLIGOF and PEC diets as compared to rats fed C, POM and CHIC diets. There was observed no difference in colonic digesta mass between groups (Table 3). In rats fed C diet, the $\mathrm{pH}$ of caecal and colonic digesta was higher when compared to the other groups. Amongst the experimental groups, the PEC and CHIC rats were associated with the lower caecal digesta $\mathrm{pH}$ than POM rats. The colonic digesta $\mathrm{pH}$ in the $\mathrm{CHIC}$ group was significantly lower than in the PEC group (Table 3). 
Table 3. Digestive tract parameters in rats

\begin{tabular}{|c|c|c|c|c|c|c|}
\hline \multirow{2}{*}{ Indices } & \multicolumn{5}{|l|}{ Diets $^{1}$} & \multirow{2}{*}{ - SEM } \\
\hline & $C$ & PEC & POM & OLIGOF & $\mathrm{CHIC}$ & \\
\hline \multicolumn{7}{|l|}{ Small intestine } \\
\hline $\begin{array}{l}\text { tissue mass } \\
\text { with digesta, } \\
\mathrm{g} \cdot 100 \mathrm{~g}^{-1} \mathrm{BW}\end{array}$ & $2.414^{c}$ & c $3.520^{\mathrm{a}}$ & a $2.700^{b}$ & $2.580^{\mathrm{bc}}$ & c $2.448^{c}$ & 0.0 \\
\hline sucrase $^{2}$ & 29.27 & 30.55 & 32.91 & 29.78 & 24.77 & $1.30 s$ \\
\hline maltase ${ }^{2}$ & $75.82^{b}$ & $94.99^{\mathrm{a}}$ & $76.92^{b}$ & $76.77^{\mathrm{b}}$ & $73.30^{\mathrm{b}}$ & 1.16 \\
\hline lactase $^{2}$ & 10.68 & 11.93 & 12.96 & 12.41 & 8.95 & 0.61 \\
\hline $\mathrm{pH}$ of digesta & $6.99^{\mathrm{a}}$ & $7.09^{a}$ & $7.01^{\mathrm{a}}$ & $6.47^{\mathrm{b}}$ & $6.91^{\mathrm{a}}$ & 0.05 \\
\hline \multicolumn{7}{|l|}{ Caecum } \\
\hline $\begin{array}{l}\text { tissue, } \\
\quad \mathrm{g} \cdot 100 \mathrm{~g}^{-1} \mathrm{BW}\end{array}$ & $0.270^{d}$ & d $0.439^{b}$ & ${ }^{b} 0.313^{\text {cd }}$ & d $0.546^{a}$ & 0.350 & 0.0 \\
\hline $\begin{array}{l}\text { digesta, } \\
\mathrm{g} \cdot 100 \mathrm{~g}^{-1} \mathrm{BW}\end{array}$ & $0.827^{b}$ & b $1.460^{\mathrm{a}}$ & a $0.984^{b}$ & $1.624^{a}$ & $1.042^{b}$ & 0.0 \\
\hline $\mathrm{pH}$ of digesta & $6.82^{\mathrm{a}}$ & $5.95^{c}$ & $6.32^{b}$ & $6.16^{\mathrm{bc}}$ & $5.93^{\mathrm{c}}$ & 0.0 \\
\hline $\begin{array}{l}\text { dry mass } \\
\text { in digesta, \% }\end{array}$ & $23.93^{a}$ & $14.81^{\mathrm{c}}$ & $18.52^{b}$ & $17.58^{b}$ & $18.15^{b}$ & 0 \\
\hline $\begin{array}{l}\text { ammonia in } \\
\text { digesta, } \mathrm{mg} \cdot \mathrm{g}^{-1}\end{array}$ & ${ }_{1} 0.358^{a}$ & a $0.267^{b}$ & b $0.230^{b}$ & $0.323^{a}$ & 0.247 & 0.01 \\
\hline \multicolumn{7}{|l|}{ Colon } \\
\hline $\begin{array}{l}\text { tissue, } \\
\qquad \mathrm{g} \cdot 100 \mathrm{~g}^{-1} \mathrm{BW}\end{array}$ & $0.523^{b}$ & b $0.523^{b}$ & b $0.519^{b}$ & $0.580^{a}$ & 0.516 & 0.0 \\
\hline $\begin{array}{l}\text { digesta, } \\
\mathrm{g} \cdot 100 \mathrm{~g}^{-1} \mathrm{BW}\end{array}$ & 0.438 & 0.412 & 0.431 & 0.456 & 0.440 & 0.03 \\
\hline $\mathrm{pH}$ of digesta & $6.80^{\mathrm{a}}$ & $6.42^{\mathrm{b}}$ & $6.31^{\mathrm{bc}}$ & $6.31^{\mathrm{bc}}$ & $6.03^{c}$ & 0.0 \\
\hline
\end{tabular}

${ }^{1}$ see Table $1 ;{ }^{2}$ activity expressed as $\mu \mathrm{mol}$ disaccharide hydrolysed per min per $g$ of protein; BW - body weight; abc - means with different superscripts within a row are significantly different at $P \leq 0.05$

Dry mass content in the caecum was significantly reduced in all experimental groups in comparison to the control group. In the PEC group the water content in ceacal digesta was the highest in comparison to other groups (Table 3). Significantly decreased ammonia concentration in the caecum was observed for all the experimental groups, except the OLIGOF group (Table 3 ).

\section{Bacterial enzyme activity and SCFA concentration in caecal digesta}

The highest caecal $\alpha$ - and $\beta$-glucosidase, $\beta$-glucuronidase and $\beta$-galactosidase activities were reported in PEC group (Table 4). Activity of particular gly-

Table 4. Bacterial enzymes activity in caecal digesta in rats

\begin{tabular}{|c|c|c|c|c|c|c|}
\hline \multirow{2}{*}{$\begin{array}{l}\text { Enzyme activity, } \\
\mu \mathrm{mol} \cdot \mathrm{h}^{-1} \cdot \mathrm{g}^{-1} \\
\text { digesta }\end{array}$} & \multicolumn{5}{|l|}{ Diets $^{1}$} & \multirow{2}{*}{ SEM } \\
\hline & C & PEC & POM & OLIGOF & $=\mathrm{CHIC}$ & \\
\hline a-glucosidase & $10.91^{c}$ & $35.43^{a}$ & $12.38^{c}$ & $23.63^{b}$ & $26.49^{a b}$ & 2.072 \\
\hline$\beta$-glucosidase & $5.29^{b}$ & $10.82^{a}$ & $6.26^{b}$ & $6.77^{\mathrm{b}}$ & $7.71^{b}$ & 0.478 \\
\hline a-galactosidase & $6.28^{b}$ & $16.86^{\mathrm{ab}}$ & $16.39^{a b}$ & $23.16^{a}$ & $24.00^{a}$ & 2.644 \\
\hline$\beta$-galactosidase & $22.97^{c}$ & $154.2^{\mathrm{a}}$ & $37.55^{c}$ & $99.05^{b}$ & $103.8^{b}$ & 9.282 \\
\hline$\beta$-glucuronidase & $18.78^{b}$ & $28.39^{a}$ & $10.13^{c}$ & $9.32^{c}$ & $6.03^{c}$ & 1.498 \\
\hline
\end{tabular}

Table 5. Short chain fatty acids (SCFA) concentration and pool size in rat caecal digesta

\begin{tabular}{|c|c|c|c|c|c|c|}
\hline \multirow{2}{*}{ Indices } & \multicolumn{5}{|l|}{ Diets $^{1}$} & \multirow{2}{*}{ SEM } \\
\hline & C & PEC & POM & OLIGOF & $=\mathrm{CHIC}$ & \\
\hline \multicolumn{7}{|c|}{ SCFA, $\mu \mathrm{mol} \cdot \mathrm{g}^{-1}$ digesta } \\
\hline acetic, C2:0 & $66.37^{c}$ & $104.8^{a}$ & $89.52^{b}$ & $59.43^{c}$ & $94.87^{b}$ & 3.169 \\
\hline propionic C3:0 & $14.39^{\mathrm{e}}$ & $33.34^{c}$ & $24.16^{d}$ & $41.36^{b}$ & $57.05^{\mathrm{a}}$ & 3.767 \\
\hline iso-butyric isoC4:0 & $0.45^{a}$ & $0.05^{\text {bc }}$ & oc $\quad 0.12^{b}$ & $0.07^{b c}$ & $=0.01^{\circ}$ & 0.031 \\
\hline butyric $\mathrm{C} 4: 0$ & $8.89^{b}$ & $5.43^{c}$ & $11.51^{\mathrm{a}}$ & $5.90^{c}$ & $6.31^{\mathrm{c}}$ & 0.500 \\
\hline iso-valeric iso $\mathrm{C} 5: 0$ & $0.61^{\mathrm{a}}$ & a $\quad 0.17^{\mathrm{b}}$ & $0.22^{b}$ & $0.23^{b}$ & $0.06^{b}$ & 0.038 \\
\hline valeric C5:0 & $1.10^{\mathrm{a}}$ & a $\quad 0.27^{\mathrm{b}}$ & $1.10^{\mathrm{a}}$ & $0.81^{a b}$ & $0.30^{\mathrm{b}}$ & 0.116 \\
\hline total SCFA & $91.8^{d}$ & $144.1^{\mathrm{ab}}$ & $126.6^{\mathrm{bc}}$ & $107.8^{\mathrm{cd}}$ & $158.6^{a}$ & 4.760 \\
\hline \multicolumn{7}{|c|}{ SCFA, $\mu \mathrm{mol}$ per caecum } \\
\hline acetic $\mathrm{C} 2: 0$ & $172^{c}$ & $440^{a}$ & $283^{b}$ & $302^{b}$ & $233^{c}$ & 19.21 \\
\hline propionic $\mathrm{C} 3: 0$ & $36.6^{c}$ & $139^{a}$ & $75.5^{c}$ & $214^{b}$ & $239^{b}$ & 15.12 \\
\hline iso-butyric iso $\mathrm{C} 4: 0$ & $1.19^{a}$ & $0.20^{b}$ & $0.40^{\mathrm{b}}$ & $0.34^{b}$ & $0.02^{b}$ & 0.087 \\
\hline butyric $\mathrm{C} 4: 0$ & $22.8^{b}$ & $23.2^{b}$ & $35.6^{a}$ & $29.3^{\mathrm{ab}}$ & $19.7^{b}$ & 1.621 \\
\hline iso-valeric iso $\mathrm{C} 5: 0$ & $1.57^{a}$ & $0.72^{\mathrm{bc}}$ & $0.73^{\text {bc }}$ & c $1.07^{\mathrm{ab}}$ & $0.20^{c}$ & 0.120 \\
\hline valeric $\mathrm{C} 5: 0$ & 2.85 & 1.09 & 3.43 & 3.53 & 0.94 & 0.436 \\
\hline total SCFA & $237^{c}$ & $604^{a}$ & $399^{b}$ & $550^{a}$ & $493^{\mathrm{ab}}$ & 28.43 \\
\hline
\end{tabular}

colytic enzymes in the caecal digesta varied depending on the administered preparation. The activities of $\alpha$-glucosidase and $\beta$-galactosidase were higher in rats receiving OLIGOF and CHIC diets than POM and C diets. The POM, OLIGOF and CHIC supplementation diminished $\beta$-glucuronidase activity in the caecal digesta in comparison to $\mathrm{C}$ group. Whereas OLIGOF and CHIC addition evoked a substantial increase in the $\alpha$-galactosidase activity, in contrast to POM and PEC groups that did not differ from $\mathrm{C}$ group (Table 4).

All additives, except OLIGOF, markedly increased the total SCFA concentration in the caecal digesta (Table 5). The concentration of total SCFA was higher in CHIC group in comparison to other groups except PEC group. The highest acetate $(\mathrm{C} 2: 0)$ concentration was observed upon the PEC diet administration, whereas the lowest - for the OLIGOF and C diets. Propionic acid (C3:0) concentration differed significantly among all experimental groups and increased in the following order: $\mathrm{C}<\mathrm{POM}<$ PEC $<$ OLIGOF $<$ CHIC. POM caused a considerable increase in butyrate $(\mathrm{C} 4: 0)$ concentration in contrast to a lowering effect of other preparations in relation to $\mathrm{C}$ group. The $\mathrm{C}$ diet was associated with the highest concentration of isovaleric (isoC5:0) and iso-butyric (isoC4:0) acids. The smallest pool of total SCFA (calculated as $\mu \mathrm{mol}$ per caecum) was observed in the control animals. 
Table 6. Antioxidant status, lipid peroxidation and biochemical serum parameters in rats

\begin{tabular}{|c|c|c|c|c|c|c|}
\hline \multirow{2}{*}{ Indices } & \multicolumn{5}{|l|}{ Diets $^{1}$} & \multirow{2}{*}{ SEM } \\
\hline & C & PEC & POM & OLIGOF & $\mathrm{CHIC}$ & \\
\hline \multicolumn{7}{|l|}{ Antioxidant parameters } \\
\hline GPx activity ${ }^{2}, \mathrm{U} \cdot \mathrm{ml}^{-1}$ & 54.94 & 57.75 & 53.70 & 53.79 & 57.06 & 0.950 \\
\hline SOD activity $^{3}, \mathrm{U} \cdot \mathrm{ml}^{-1}$ & 327.90 & 319.00 & 359.30 & 333.80 & 337.00 & 7.069 \\
\hline ACW, mmol ascorbic acid $\cdot \mathrm{ml}^{-1}$ & 0.070 & 0.069 & 0.072 & 0.056 & 0.071 & 0.006 \\
\hline $\mathrm{ACL}, \mathrm{mmol}$ Trolox $\cdot \mathrm{ml}^{-1}$ & 0.045 & 0.047 & 0.047 & 0.043 & 0.044 & 0.001 \\
\hline \multicolumn{7}{|l|}{ TBARS content, $\mu \mathrm{mol} \cdot 100 \mathrm{~g}^{-1}$ tissue } \\
\hline kidney & $15.19^{\mathrm{a}}$ & $13.34^{\mathrm{ab}}$ & $11.12^{\mathrm{b}}$ & $14.27^{\mathrm{ab}}$ & $12.89^{\mathrm{ab}}$ & 0.743 \\
\hline liver & 5.383 & 5.630 & 5.186 & 5.043 & 4.966 & 0.102 \\
\hline heart & 3.753 & 3.835 & 3.547 & 3.714 & 3.453 & 0.082 \\
\hline lungs & 5.181 & 5.301 & 5.100 & 5.498 & 5.463 & 0.099 \\
\hline \multicolumn{7}{|l|}{ Serum } \\
\hline ALT activity, $\mathrm{U} \cdot \mathrm{I}^{-1}$ & 14.69 & 12.59 & 13.52 & 13.80 & 14.23 & 0.487 \\
\hline AST activity, $\left.U \cdot\right|^{-1}$ & 145.50 & 140.40 & 143.40 & 140.40 & 147.00 & 3.358 \\
\hline glucose content, $\mathrm{mmol} \cdot \mathrm{I}^{-1}$ & 11.8 & 10.7 & 11.4 & 10.8 & 11.5 & 0.224 \\
\hline TAG content, $\mathrm{mmol} \cdot \mathrm{I}^{-1}$ & $1.83^{\mathrm{a}}$ & $1.37^{\mathrm{bc}}$ & $1.32^{c}$ & $1.53^{b}$ & $1.45^{\mathrm{bc}}$ & 0.037 \\
\hline $\mathrm{TC}$ content, $\mathrm{mmol} \cdot \mathrm{I}^{-1}$ & $2.84^{a}$ & $1.66^{c}$ & $2.24^{b}$ & $2.23^{b}$ & $2.12^{b}$ & 0.058 \\
\hline $\mathrm{HDL}$ content, $\mathrm{mmol} \cdot \mathrm{I}^{-1}$ & $1.03^{\mathrm{ab}}$ & $0.92^{\mathrm{b}}$ & $1.01^{a b}$ & $1.08^{\mathrm{a}}$ & $0.97^{\mathrm{ab}}$ & 0.019 \\
\hline HDL : TC, $\%$ & $36.29^{c}$ & $55.52^{\mathrm{a}}$ & $45.34^{b}$ & $48.75^{b}$ & $45.96^{\mathrm{b}}$ & 1.291 \\
\hline
\end{tabular}

${ }^{1}$ see Table 1; GPx - glutathione peroxidase, SOD - superoxide dismutase, ACW - antioxidant capacity of water-soluble serum fraction, ACL - antioxidant capacity of lipid-soluble serum fraction, TBARS - thiobarbituric acid reactive substances, ALT - alanine transaminase, AST - aspartate aminotransferase, TAG - triacyloglycerol, TC - total cholesterol, HDL - high-density lipoprotein; ${ }^{2} \mathrm{GPx}$ activity in the whole blood; ${ }^{3} \mathrm{SOD}$ activity in the erythrocytes; ${ }^{a b c}$ - means with different superscripts within a row are significantly different at $P \leq 0.05$

The $\mathrm{C}$ group was characterized by the smaller $\mathrm{C} 2$ in comparison to PEC, POM, OLIGOF groups and smaller $\mathrm{C} 3$ pool in comparison to PEC, OLIGOF and CHIC. Also in $\mathrm{C}$ group pool of iso-butyric acid and iso-valeric acid were greater in comparison to all groups and to PEC, POM and CHIC, respectively. The greater butyric acid pool was observed in POM in comparison to C, PEC and CHIC groups. As compared to the PEC treatment, the POM was characterized by a smaller pool of total SCFA, acetic and propionic acids, but a significantly greater butyric acid pool. Considering OLIGOF and CHIC, the latter was associated with a smaller pool of acetic and iso-valeric acids.

\section{Biochemical blood indices and antioxidant status}

Serum glucose concentration, and ALT and AST activities remained unaffected by dietary treatments. Feeding rats with diet supplemented with POM decreased TBARS level in the kidney in comparison to rats fed $\mathrm{C}$ diet (Table 6). For the liver, heart and lungs there was no statistically significant difference between the groups with regard to TBARS content. Other examined indices of antioxidant status, i.e. GPx activity in blood, SOD activity in erytrocytes, serum ACW and ACL, were also unaffected.
In comparison to $\mathrm{C}$, in all treatments it was displayed significantly lower TAG level, whereas POM rats had lower TAG content than OLIGOF rats. TC levels were decreased in all experimental groups in comparison to $\mathrm{C}$ group, but PEC diet reduced TC content more than other treatments. In OLIGOF rats it was observed greater effect on elevating the HDL cholesterol level in comparison to PEC rats. The highest HDL : TC ratio was observed in PEC, while it was the lowest in $\mathrm{C}$ group (Table 6).

\section{Discussion}

In our study, we looked into the nutritional and biochemical effects of plant preparation containing both non-digestible saccharides and polyphenols.

PEC exerted its distinct effect on diet utilization by decreasing the daily diet intake and, consequently, decreasing the BW gain. These results are in line with the results of other studies (Aprikian et al., 2003; Pirman et al., 2007). It is assumed that pectin added to the diet stimulates protein metabolism in digestive tract tissues, thus reduces availability of amino acids and energy for other tissues. Furthermore, in alimentary tract pectin acquires a gel-like consistency, increases satiety and reduces 
the overall food intake (Pirman et al., 2007). These properties of pectin contribute to reduction of BW as a result of apple consumption (Conceição de Oliviera et al., 2003).

It was also revealed that supplementing rats with PEC, and to a lesser extent POM, increased the small intestinal mass. Other researchers have also shown a similar effect of pectin (Pirman et al., 2007; Taciak et al., 2015), which may result from accumulation of a high-moisture and viscous digesta and from its prolonged passage through the proximal part of the digestive tract. Pectin increased also maltase activity in the small intestine, which might be an adaptive response to greater digesta weight and viscosity but also to morphological changes as it was indicated by Schwarz et al. (1983) and Koruda et al. (1988). Furthermore, Fotschki et al. (2014) demonstrated that the apple fibre preparation, after pectinase treatment, significantly reduced the sucrase and maltase activities in the small intestinal mucosa.

The results of this study indicated the trophic effect of OLIGOF on the caecum which is in line with data previously reported by Zduńczyk et al. (2006). The mechanism responsible for dietary effects of OLIOGOF may be related to stimulation of bacterial growth (especially bifidobacteria). Such changes within the gut microflora may promote both colonic and systemic health (Han et al., 2014). Oligofructose can be rapidly and completely fermented by the colonic microflora with the production of acetate and other SCFA. SCFA stimulate blood flow and hormone secretion in intestinal wall and which in turn additionally stimulate cell proliferation in the large intestine (Hippe et al., 2015).

The pectin-induced trophic effect in the large intestine has been related not only to SCFA activity, but also to the pectin ability to bind water and thus increase the volume of digesta (Adam et al., 2015).

In the presented study, experimental diets significantly modulated $\mathrm{pH}$ of different parts of the intestine. Data suggests that bacteria in the distal part of the small intestine utilize some types of fibre and increase acidity of digesta (Tuohy et al., 2005). In this experiment, the decreased $\mathrm{pH}$ of small intestinal digesta was observed only in rats fed OLIGOF diet. Our findings suggest that intestinal microflora more readily utilizes oligofructose as compared to apple pectins and inulin from CHIC. Indeed, some studies demonstrated that the susceptibility of prebiotic oligosaccharides to bacterial fermentation is determined by the length of their carbohydrate chain (Juśkiewicz et al., 2008). Furthermore, we observed that the $\mathrm{pH}$ of the large intestinal digesta significantly decreased with substitution of the cellulose with apple preparations. However, PEC acidified mostly the caecal digesta, whilst POM had similar acidifying effect on both the caecal and colonic content. It can be concluded that fermentation of pectins was more intensive in the proximal part of the large intestine, whilst POM fermentation in the large intestine remained steady throughout. In a similar experiment on rats, diet supplemented with $8 \%$ of pectin significantly decreased $\mathrm{pH}$ not only in the caecum and colon, but also in the small intestine (Pirman et al., 2007).

All examined preparations beneficially reduced concentration of ammonia in the caecal digesta, with OLIGOF exerting the smallest effect. Further studies are required to clarify the dietary effects of poly- and oligosaccharides and their combination with polyphenols on nitrogen balance. The data suggests that oligofructose can stimulate intensive growth of bacteria and, consequently, increase demand for blood urea as a nitrogen source (Zduńczyk et al., 2006).

The modulatory physiological effect of the dietary ingredients as fibre and polyphenols was also manifested by the changes in the enzymatic activity of caecal microbiota. Previous studies conducted in our laboratory as well as those by other researchers revealed that inclusion of dietary fructans, apple pomace and polyphenolic fraction from chicory and apple significantly decreased activity of $\beta$-glucuronidase released from bacterial cells into the large gut environment (Bouhnik et al., 2007; Juśkiewicz et al., 2011, 2012). Among all experimental preparations, pectin was the only one associated with markedly increased activity of $\beta$-glucuronidase. This enzyme, characteristic of harmful bacteria species, has deconjugative properties that support transformation of xenobiotics into more toxic substances (Hambly et al., 1997). In this study, beneficial modulatory effect of chicory fructans on enzymatic profile was clearly observed in the OLIGOF and CHIC groups as indicated by the aforementioned inhibitory effect on $\beta$-glucuronidase and stimulating on $\alpha$-glucosidase, $\alpha$-galactosidase and $\beta$-galactosidase activities. Interestingly, there was no effect of dietary chicory polyphenols on bacterial enzymatic activity. Such effect was noted in case of apple preparations, as the POM group was characterized by significantly lower activities of $\alpha$ - and $\beta$-glucosidase, $\beta$-galactosidase and $\beta$-glucuronidase in comparison to PEC group.

It is claimed that in case of oligosaccharides with a different susceptibility to fermentation, the SCFA pool size (considering the digesta bulk in the 
caecum) is a good indicator of fermentation processes in the intestines (Topping and Clifton, 2001). In this study, we observed significant changes in the concentration and pool size of SCFA in the caecum. The highest concentration and pool size of acetic acid was seen upon PEC administration, which has been also previously reported by other authors (Aprikian et al., 2003; Pirman et al., 2007). In the POM-fed group a shift from acetatepropionate- towards butyrate-type fermentation was observed, suggesting alterations in the microflora profile which would be in agreement with findings by Louis et al. (2007). Altered profile of the microflora might be responsible for differences between the PEC and POM groups in glycolytic activity and acidification of the caecal digesta. With respect to CHIC and OLIGOF, an increased concentration and pool size of propionic acid was observed. Importantly, the marked rise in the concentration and pool of butyric acid demonstrated for POM might have an impact on cancerous cells of the colon epithelium. One of the properties of butyric acid and some of its derivatives is inhibition of histone deacetylation, closely related to suppression of carcinogenesis in the colon. In this respect, acetic acid appeared to be inactive and propionic acid revealed only a medium inhibition (Hong et al., 2015). The total SCFA concentration was higher in rats fed CHIC than in the animals fed OLIGOF. It is plausible, that the latter was related to the increased accumulation of digesta in the caecum. Indeed, the chicory products, and other products that contain prebiotic fructans, oligofructose and inulin, were shown to exert a stimulatory effect on gastrointestinal bacteria and SCFA production (Louis et al., 2007; Han et al., 2014).

Our results demonstrated that POM diet affected the lipid peroxidation in the kidneys. This could be connected with the intensive caecal fermentation of apple fibre, which would promote apple polyphenol metabolism in the gut, leading to polyphenol absorption and circulation in the body.

The dietary treatments with apple and chicory preparations resulted in beneficial changes in serum lipid profile, as indicated by lower TAG and total cholesterol concentration in comparison to the control animals. It may be associated with the changes in caecal fermentative processes, i.e. increased propionic acid concentration, which could have beneficial impact on lipid metabolism proportional to its amount (Hippe et al., 2015). Also, the beneficial modulatory effect of dietary fibre and polyphenols from apple and chicory was confirmed by significantly higher HDL to total cholesterol ratio in all experimental groups.

\section{Conclusions}

Diets with apple pomace and chicory root meal addition, both containing dietary fibre and polyphenols, beneficially affect serum lipid profile and the caecal microbiota activity in rats.

\section{References}

Adam C.L., Williams P.A., Garden K.E., Thomson L.M., Ross A.W., 2015. Dose-dependent effects of a soluble dietary fibre (pectin) on food intake, adiposity, gut hypertrophy and gut satiety hormone secretion in rats. PLOS ONE, 10, e0115438, doi:10.1371/ journal.pone.0115438

AOAC International, 2005. Official Methods of Analysis of AOAC International. $18^{\text {th }}$ Edition. Gaithersburg, MD (USA)

Aprikian O., Duclos V., Guyot S., Besson C., Manach C., Bernalier A., Morand C., Rémésy C., Demingé C., 2003. Apple pectin and a polyphenol-rich apple concentrate are more effective together than separately on caecal fermentation and plasma lipids in rats. J. Nutr. 133, 1860-1865

Bouhnik Y., Raskine L., Champion K., Andrieux C., Penven S., Jacobs H., Simoneau G., 2007. Prolonged administration of low-dose inulin stimulates the growth of bifidobacteria in humans. Nutr. Res. 27, 187-193

Conceição de Oliviera M., Sichieri R., Moura A.S., 2003. Weight loss associated with a daily intake of three apples or three pears among overweight women. Nutrition 19, 253-256

Dahlqvist A., 1964. Method for assay of intestinal disaccharidases. Anal. Biochem. 7, 18-25

Fotschki B., Jurgoński A., Juśkiewicz J., Kołodziejczyk K., Sójka M., 2014. Effects of dietary addition of a low-pectin apple preparation on rats. Pol. J. Food Nutr. Sci. 64, 193-199

Hambly R.J., Rumney C.J., Cunninghame M., Fletcher J.M.E., Rijken P.J., Rowland I.R., 1997. Influence of diets containing high and low risk factors for colon cancer on early stages of carcinogenesis in human-flora-associated (HFA) rats. Carcinogenesis 18, 1535-1539

Han K.-H., Kobayashi Y., Nakamura Y., Shimada K., Aritsuka T., Ohba K., Morita T., Fukushima M., 2014. Comparison of the effects of longer chain inulins with different degrees of polymerization on colonic fermentation in a mixed culture of swine fecal bacteria. J. Nutr. Sci. Vitaminol. 60, 206-212

Hippe B., Remely M., Aumueller E., Pointner A., Haslberg A.G., 2015. SCFA producing gut microbiota and its effects on the epigenetic regulation of inflammation. In: M.-T. Liong (Editor). Beneficial Microorganisms in Medical and Health Applications. Microbiology Monographs. Vol. 28. Springer International Publishing AG. Cham (Switzerland), pp. 181-197

Hong M.Y., Turner N.D., Murphy M.E., Carroll R.J., Chapkin R.S., Lupton J.R., 2015. In vivo regulation of colonic cell proliferation, differentiation, apoptosis and P27 ${ }^{\text {Kip1 }}$ by dietary fish oil and butyrate in rats. Cancer Prev. Res. 8, 1076-1083

Juśkiewicz J., Zduńczyk Z., Jurgoński A., Brzuzan Ł., Godycka-Kłos I., Żary-Sikorska E., 2008. Extract of green tea leaves partially attenuates streptozotocin-induced changes in antioxidant status and gastrointestinal functioning in rats. Nutr. Res. 28, 343-349 
Juśkiewicz J., Zduńczyk Z., Żary-Sikorska E., Król B., Milala J., Jurgoński A., 2011. Effect of the dietary polyphenolic fraction of chicory root, peel, seed and leaf extracts on caecal fermentation and blood parameters in rats fed diets containing prebiotic fructans. Brit. J. Nutr. 105, 710-720

Juśkiewicz J., Żary-Sikorska E., Zduńczyk Z., Król B., Jarosławska J., Jurgoński A., 2012. Effect of dietary supplementation with unprocessed and ethanol-extracted apple pomaces on caecal fermentation, antioxidant and blood biomarkers in rats. Brit. J. Nutr. 107, 1138-1146

Koruda M.J., Rolandelli R.H., Settle R.G., Rombeau J.L., 1988. Small bowel disacchridase activity in the rat as affected by intestinal resection and pectin feeding. Am. J. Clin. Nutr. 47, 448-453

Louis P., Scott K.P., Duncan S.H., Flint H.J., 2007. Understanding the effects of diet on bacterial metabolism in the large intestine. J. Appl. Microbiol. 102, 1197-1208

Lowry O.H., Rosebrough N.J., Farr A.L., Randall R.J., 1951. Protein measurement with the Folin phenol reagent. J. Biol. Chem. 193, 265-275

Milala J., Grzelak K., Król B., Juśkiewicz J., Zduńczyk Z., 2009. Composition and properties of chicory extracts rich in fructans and polyphenols. Pol. J. Food Nutr. Sci. 59, 35-43

Olthof M.R., Hollman P.C.H., Katan M.B., 2001. Chlorogenic acid and caffeic acid are absorbed in humans. J. Nutr. 131, 66-71

Pirman T., Ribeyre M.C., Mosoni L., Rémond D., Vrecl M., Salobir J., Mirand P.P., 2007. Dietary pectin stimulates protein metabolism in the digestive tract. Nutrition 23, 69-75
Schwartz S.E., Starr C., Bachman S., Holtzapple P.G., 1983. Dietary fiber decreases cholesterol and phospholipid synthesis in rat intestine. J. Lipid Res. 24, 746-752

Taciak M., Barszcz M., Tuśnio A., Pastuszewska B., 2015. Interactive effects of indigestible carbohydrates, protein type, and protein level on biomarkers of large intestine health in rats. PLoS ONE 10, e0142176, doi:10.1371/journal.pone.0142176

Topping D.L., Clifton P.M., 2001. Short-chain fatty acids and human colonic function: Roles of resistant starch and nonstarch polysaccharides. Physiol. Rev. 81, 1031-1064

Tuohy K.M., Rouzaud G.C.M., Brück W.M., Gibson G.R., 2005. Modulation of the human gut microflora towards improved health using prebiotics - assessment of efficacy. Curr. Pharm. Design 11, 75-90

Uchiyama M., Mihara M., 1978. Determination of malonaldehyde precursor in tissues by thiobarbituric acid test. Anal. Biochem. $86,271-278$

Wolfe K.L., Liu R.H., 2003. Apple peels as value-added food ingredient. J. Agr. Food Chem. 51, 1676-1683

Wronkowska M., Juśkiewicz J., Zduńczyk Z., Soral-Śmietana M., Krupa-Kozak U., 2011. Influence of chemically-modified potato starch (RS type 4) on the nutritional and physiological indices of rats. Pol. J. Food Nutr. Sci. 61, 143-151

Zduńczyk Z., Juśkiewicz J., Estrella I., 2006. Cecal parameters of rats fed diets containing grapefruit polyphenols and inulin as single supplements or in a combination. Nutrition 22, 898-904 